\section{Revista}

A Cor das Letras
Revista Digital dos Programas de

Pós-Graduação do Departamento de Letras e Artes da UEFS

Feira de Santana, v. 20, n. 3, p. 92-110, dezembro de 2019

http://periodicos.uefs.br/index.php/acordasletras/index

do http://dx.doi.org/10.13102/cl.v20i2.4830

\title{
As velhas novas casas de Usher
}

\author{
Usher's old new houses
}

\author{
Juliana Rodrigues Salles* \\ Universidade Federal da Babia \\ Salvador, Bahia, Brasil \\ Mirella Márcia Longo Vieira Lima** \\ Universidade Federal da Babia \\ Salvador, Bahia, Brasil
}

\begin{abstract}
Resumo: Edgard Allan Poe ao escrever um conto intitulado A Queda da Casa de Usher, em 1839, trouxe a história da saga de dois irmãos, últimos descendentes de uma linhagem nobre, de uma família antiga e ilustre, porém decadente, que sucumbem junto com a mansão que habitam. Essa obra tem pontos em comum com Os Maias, de Eça de Queirós e também com A Crônica da Casa Assassinada, de Lúcio Cardoso em muitos aspectos, desde alguns pontos no enredo até na descrição das casas e seus antropomorfismos. Ao analisar passagens das obras, vemos que Eça de Queirós e Lúcio Cardoso "bebem” da literatura gótica para descrever partes das casas em que as tramas se apresentam, criando uma atmosfera de decadência e finitude.
\end{abstract}

Palavras-Chave: Família; Decadência; Finitude.

\begin{abstract}
Edgard Allan Poe, writing a short story titled The Fall of the House of Usher in 1839, brought the story of two brothers, the last descendants of a noble lineage, of an ancient and illustrious but decaying family who succumb along with the mansion. who inhabit. This work has points in common with Os Maias, by Eça de Queirós and also with The Chronicle of the Murdered House, by Lucio Cardoso in many ways, from some points in the plot to the description of the houses and their anthropomorphisms. In analyzing passages from the works, we see that Eça de Queirós and Lúcio Cardoso have inspiration from Gothic literature to describe parts of the houses in which the plots appear, creating an atmosphere of decay and finitude.
\end{abstract}

Keywords: Family; Decay; Finitude

\section{A CHÁCARA, DA CRÔNICA DA CASA ASSASSINADA E O RAMALHETE, DE OS MAIAS: AS VELHAS NOVAS CASAS DE USHER}

Em Espaço e Romance, Antônio Dimas afirma que "entre as várias armadilhas virtuais de um texto, o espaço pode alcançar estatuto tão importante quanto outros componentes da narrativa, tais como foco narrativo, personagem, tempo, estrutura" (DIMAS, 1994. p.1), portanto, o espaço no romance pode adquirir um status de muita relevância e decretar os caminhos a serem tomados nas obras.

* Doutoranda em Literatura e Cultura pela Universidade Federal da Bahia. Professora de Língua Inglesa do Estado da Bahia. E-mail: julaysalles@hotmail.com.

** Doutora em Letras. Professora Titular de Teoria Literária e Literatura Comparada da UFBA. E-mail: mirella@ufba.br. 
Não é novidade que o espaço - e particularmente as edificações - tem papéis de destaque no decorrer das tramas. Pode-se exemplificar Edgard Allan Poe e sua A queda da casa de Usher, que vai trazer a casa como personagem que se desenvolve e atua dentro da trama e tem processo significativo em seu desfecho. A importância da Casa é evidente na Crônica da Casa Assassinada, representada pela Chácara e nos Maias, representada pelo Ramalhete. Elas são testemunhas das trágicas crônicas das famílias.

Bachelard, em Poética do espaço discorre sobre a casa, o elo com o passado e com a tradição:

[...] a casa é uma das maiores (forças) de integração para os pensamentos, as lembranças e os sonhos do homem. Nessa integração, o princípio de ligação é o devaneio. O passado, o presente e o futuro dão a casa dinamismos diferentes, dinamismos que não raro interferem, às vezes se opondo, às vezes excitando-se mutuamente. $\mathrm{Na}$ vida do homem, a casa afasta contingências, multiplica seus conselhos de continuidade. Sem ela, o homem seria um ser disperso. Ele mantém o homem através das tempestades do céu e das tempestades da vida. É o corpo e é alma. É o primeiro mundo do ser humano. (BACHELARD, ANO, p.26).

As casas, nos dois romances, têm uma forte ligação com a tradição e com o passado da família e trazem, por gerações, segurança e abrigo. Mas, as relações humanas dentro dessas famílias estão em franco processo de desmoronamento e, por consequência, as casas acompanham esses processos e são incapazes de resistir à desintegração, morrendo junto aos clãs e suas tradições.

Lúcio Cardoso e Eça de Queirós transformaram os espaços em protagonistas que se transfiguram. As casas têm um protagonismo evidente, deixam de ser coadjuvantes ou simples acessórios, modificando-se e sucumbindo à ruína junto às outras personagens. Nos romances, as casas são dotadas de alma e estão intimamente ligadas aos acontecimentos: "Sim, essas velhas casas mantinham vivo um espírito identificável, capaz de orgulho, de sofrimento e, por que não, de morte também, quando arrastadas à mediocridade e ao chão dos seres comuns." (CARDOSO, P.259) todo o ambiente vai sofrendo e se deteriorando à medida em que as famílias também começam o processo de desagregação. Ao fazermos uma varredura no espaço das casas dos Maias e da Crônica, vemos que as edificações aprisionam, dominam e devoram os seus habitantes. São ambientes cheios de presságios e de simbologias que denotam a faina da morte.

Edgard Allan Poe escreveu um conto intitulado A Queda da Casa de Usher, em 1839. A história conta a saga de dois irmãos, últimos descendentes de uma linhagem nobre, de uma família antiga e ilustre, porém decadente, que sucumbem junto com a mansão que habitam. Essa obra tem pontos em comum com Os Maias e também com A Crônica em muitos aspectos, desde alguns pontos no enredo até na descrição das casas e seus antropomorfismos.

A casa pode significar muito mais que um lar ou uma moradia. A casa é o primeiro abrigo, porto seguro, ponto de referência e pode simbolizar também a riqueza e o status social; por muitas vezes, a casa é o prolongamento, o espelho dos seus moradores. Nesse conto, "A casa de Usher significava, para as pessoas do distrito, não só a casa e terra, mas também a família." (The fall of house of Usher, p.27). Os próprios moradores da cidade 
afirmavam que a casa e a família eram a mesma unidade. A casa arruinada coincidiu com a ruína da família. O cenário é composto por vegetação selvagem, cercado por árvores mortas e decaído, a mansão deteriorada por fora e por dentro, velha, de paredes cinzentas, marcada por uma grande rachadura em uma atmosfera decadente, sombria e imóvel. Um incesto se consuma e a morte se instala. Findam-se a casa e a família. A casa é soberana e é animizada; tanto quanto os representantes da família, ela tem vida, sente as dores e sofre modificações da psique, concentrando, em sua queda, o final trágico da história. A narrativa é atravessada por palavras como "morto", "vazio", “jaziam”, "agonia” etc. Há o destaque para o excesso de luxo incômodo e para os vários tons que assumem a ruína:

[...] a simples casa, a simples paisagem característica da propriedade, os frios muros, as janelas que se assemelhavam a olhos vazios, algumas fileiras de carriços e uns tantos troncos apodrecidos[...] (POE, 1981. p.7)

O mobiliário geral era excessivo, incômodo, antigo e estragado. Muitos livros e instrumentos musicais jaziam espalhados em torno, mas não conseguiam dar vitalidade alguma ao ambiente. (Poe. 1981. P.11)

A expressão jazer traz o sentido de algo morto ou que parece estar morto. Dessa forma, mesmo os móveis e acessórios opulentos que poderiam dar ideia de prazer e aconchego causam uma impressão contrária. Há recorrência também no fato de que as janelas, que seriam os olhos da casa, não se abrem ou não permitem a entrada de luz.

Os enredos de Os Maias e da Crônica da Casa Assassinada se aproximam em todos esses pontos apontados na Queda da Casa de Usher. Ao analisar passagens das obras, vemos que Eça de Queirós e Lúcio Cardoso "bebem” da literatura gótica para descrever partes das casas em que as tramas se apresentam. As narrativas desses romances têm traços da literatura gótica que, segundo Briget M. Marshall (2013) "é um gênero extraordinariamente flexível que tem se adaptado e florescido em uma variedade de países ao longo de alguns séculos"(p.3). Marshall explica que outros elementos como os castelos arruinados das histórias tradicionais góticas britânicas renderam subtipos como as plantations, as imensas propriedades de latifúndio no sul dos Estados Unidos perdidas em meio à paisagem com evidentes sinais de deterioração e ruínas. Apesar de algumas "modernizações", a literatura gótica mantém muitas das suas características originais:

A plantation sulista [com sua casa-grande] funciona bem como substituta dos castelos góticos tradicionais devido à sua referência simbólica a uma aristocracia decaída. Assim como os castelos arruinados fazem alusão à perda da riqueza e poder de uma geração mais antiga, o estado arruinado da plantation sulista no período após a Guerra Civil americana refere-se à história da classe dos latifundiários, e, de fato, a todo o sul dos Estados Unidos de uma maneira geral. O espaço físico da casa-grande (assim como o do castelo) ecoa a natureza decaída dos habitantes com seus numerosos aposentos, faustosos no passado, mas agora deteriorados. Tanto as casas-grandes quanto os castelos remetem a um passado perdido... (MARSHALL, 2013. p. 7 apud BARROS, 2014)

Não são raras as passagens em que as edificações dos Maias e da Crônica remetem às histórias fantasmagóricas em que a decadência, a ruína e o ambiente lúgubre, funesto 
e, por vezes aterrorizante, constituem uma visão, uma casca de algo que fora muito opulente e próspero em tempos áureos. As casas são reiteradamente descritas como isoladas e lúgubres, abandonadas e à mercê de uma vegetação selvagem. Tanto Lúcio Cardoso quanto Eça de Queirós foram capazes de transpor para suas obras as classes que eram dominantes, mas que caíram em franca decadência, coincidindo com a ruína das casas e negando qualquer possibilidade de regeneração.

As casas em ruínas e prestes a desmoronar associadas ao tombamento de gerações, a certa nostalgia em relação ao passado e a total desesperança em relação ao futuro também são ecos do Decadentismo, que atravessa os dois romances. Em acordo com Haquira Osakabe:

Quando se fala em decadentismo e quando, pela primeira vez, foi feita a alusão a essa tendência finissecular, tinha-se pouca ideia das verdadeiras implicações desse termo. A glamourização da palavra acabou por atenuar o impacto da substancial transformação pela qual o século estaria passando, ocultando em boa parte o estado de profunda depressão que iria sofrer a Europa. E essa depressão resultava não tanto do declínio de um tipo particular de sociedade, mas da dissolução da tradição ética que o mundo ocidental teria erigido para si. Nesse sentido, o decadentismo foi muito mais que uma deposição de armas: foi a manifestação de um estado de espírito em que o homem sente-se mortalmente atingido no seu próprio cerne. (2002, p. 30-31)

O decadentismo está intimamente ligado ao momento finissecular europeu, ao qual Eça de Queirós não ficou completamente imune. Esse movimento traduz o abalo da fé no cientificismo, positivismo e modernização como soluções para os males das gerações anteriores. Foram esperanças que ruíram, como a Chácara e como o Ramalhete. Essa ruína foi composta por sentimento de falência, fracasso, apatia e depressão. Todo o esforço humano passou a ser considerado inútil, pois a tendência seria a decomposição do mundo. Esse desalento e negativismo se reflete nas obras em questão que trazem a impossibilidade de renovação e a ideia de finitude como pontos nodais. Não se pode classificar Eça de Queirós ou Lúcio Cardoso como expoentes da literatura gótica ou como decadentistas, mas se podem perceber ecos dessas tendências em suas escritas.

A Chácara e o Ramalhete sofrem de defeitos fundamentais: a desertificação, a falta de luminosidade e o exagero de silêncio, pois no Ramalhete "todo rumor de passos morria" e na Chácara "como sempre também, a casa parecia deserta, e em torno dela não se ouvia o menor rumor” (CARDOSO, 2009, p. 146). O Ramalhete, com a melancolia de mosteiro, padecia de uma escuridão interna reiterada com as passagens referentes às chamas das velas extintas ou a se extinguir. A luz, como metáfora da vida, aparece muitas vezes em processo de acabamento, de finitude. Até mesmo a luz do sol, como fonte de calor e vida, era cerceada por janelas cerradas ou de vidros foscos nos dois romances. A Chácara tinha um problema com luz elétrica, que era fria e deficiente, o que causava um aspecto permanentemente penumbroso. A falta de luz nesses ambientes, ou melhor, o impedimento da entrada da luz simboliza a ausência da força vital e realça a atmosfera de decadência, da condenação à morte. As particularidades desses ambientes assombrados, assombrosos e nebulosos se fundem com o esfacelamento social e moral das outras personagens. 
Dotadas de "alma”, as casas são testemunhas das histórias, tristezas e façanhas das famílias. Os símbolos de ostentação e poder escondem, em suas paredes, coisas graves, laceradas, "dessas que ocorrem subterraneamente no seio das famílias" (CARDOSO, 2009 , p. 144). Eram paredes acostumadas a acompanhar e suportar vários desgostos domésticos. As lendas e façanhas referentes a cada uma delas mantinha o prestígio e a tradição da família nos arredores, mas, por outro lado, essa tradição se tornara cada vez mais difícil de ser mantida, já que o processo de dispersão e abandono nas duas famílias se apresentavam de modo acelerado e irreversível:

E seria para ele como o horror de uma fatalidade! Já a mulher de seu filho fugira com um homem, deixando atrás de si um cadáver, seu neto agora fugia também, arrebatando a família doutro - e a história da sua casa tornava-se assim uma repetição de adultérios, de fugas, de dispersões, sob o bruto aguilhão da carne! (QUEIRÓS, p. 92, V.2)

Meneses todos, que através de lendas, fugas e romances, de uniões e histórias famosas, tinham criado a "alma" da residência, aquilo que, incólume e como suspenso no espaço, sobreviveria, ainda que seus representantes mergulhassem para sempre na obscuridade. (CARDOSO, p. 258-259)

Ao começarmos pelo Ramalhete em Os Maias, vê-se no princípio do romance que a edificação está desabitada há um longo tempo, precisava de muitas reformas e carregava lembranças de um passado ruim, ou seja, era uma casa condenada, carregada de um peso funesto de fatalidades familiares. Considerada pelo administrador como um "inútil pardieiro" e excessivamente dispendiosa, era improvável que voltasse a ser um lar. Vejamos:

Afonso assombrou Vilaça anunciando-lhe que decidira vir habitar o Ramalhete! O procurador compôs logo um relatório a enumerar os inconvenientes do casarão: o maior era necessitar tantas obras e tantas despesas; depois, a falta de um jardim devia ser muito sensível a quem saía dos arvoredos de Santa Olávia; e por fim aludia mesmo a uma lenda, segundo a qual eram sempre fatais aos Maias as paredes do Ramalhete, $<<$ ainda que (acrescentava ele numa frase meditada) até me envergonho de mencionar tais frioleiras neste século de Voltaire, Guizot e outros filósofos liberais...>>

Afonso riu muito da frase, e respondeu que aquelas razões eram excelentes mas ele desejava habitar sob tetos tradicionalmente seus; se eram necessárias obras, que se fizessem e largamente; e enquanto a lendas e agouros, bastaria ir de par em par as janelas e deixar entrar o sol. (QUEIRÓS, 1997, v.1, p.1042)

Afonso da Maia, de educação racional e de moldes ingleses em nada acreditava em superstições, mas alguns traços da antiga residência o incomodavam:

O que desconsolara Afonso, ao princípio, fora a vista do terraço - donde outrora, decerto, se abrangia até o mar. Mas as casas edificadas em redor, nos últimos anos, tinham tapado esse horizonte esplêndido. Agora, uma estreita tira de água e monte que se avistava entre dois prédios de cinco andares, separados por um corte de rua, formava toda a paisagem defronte do Ramalhete. (QUEIRÓS, 1997, v.1, p. 1045). 
A imagem remonta aos tempos áureos dos Maias e muito se relaciona ao percurso da família. Com o passar do tempo em que estivera desabitado, o Ramalhete ficara isolado, não podendo mais observar o horizonte. Pode-se dizer que simbolizava a tradição da família, que estava se estreitando.

Outra imagem muito recorrente é a comparação do Ramalhete com a seriedade e severidade clerical. A influência dos Padres e das instituições religiosas é nítida na construção:

Em 1858 monsenhor Buccanni, núncio de Sua Santidade, visitara-o com ideia de instalar lá a nunciatura, seduzido pela gravidade clerical do edifício e pela paz dormente do bairro. $[\cdots]$

Apesar deste fresco nome de vivenda campestre, o Ramalhete, sombrio casarão de paredes severas, com um renque de estreitas varandas de ferro no primeiro andar, e por cima uma tímida fila de janelinhas abrigadas à beira do telhado, tinha o aspecto tristonho de residência eclesiástica, que competia a uma edificação do reinado da Sra. D. Maria I: com uma sineta e com uma cruz no topo, assemelhar-se-ia a um colégio de Jesuítas. Longos anos o Ramalhete permanecera desabitado, com teias de aranha pelas grades dos postigos térreos, e cobrindo-se de tons de ruína... e o Ramalhete possuía apenas, ao fundo de um terraço de tijolo, um pobre quintal inculto, abandonado às ervas bravas, com um cipreste, um cedro e uma cascatazinha seca, um tanque entulhado, e uma estátua de mármore (onde Monsenhor reconheceu logo Vênus Citereia) enegrecendo a um canto na lenta umidade das ramagens silvestres. (QUEIRÓS, 1997, v.1, p.1041)

Antes da reforma que devolveria, ainda que provisoriamente, todo o seu esplendor, o Ramalhete já sentia os sinais da derrota, invadido por ervas daninhas, pela umidade e teias de aranha. Mesmo após a reforma, o mobiliário luxuoso e excessivo também não combinava com a harmonia de um lar. A opulenta mansão, que deveria ser algo iluminado e vivo é traduzida como uma espécie de museu, com um mobiliário frio e aposentos cheios de melancolia, um posto de clausura prestes a ser abandonado e se converter em ruínas. $\mathrm{O}$ aspecto de residência eclesiástica era lembrado até pelos próprios moradores da casa: "Carlos lamentava também que uma existência de solteirões lhe impedisse, a ele e ao avô, de receberem senhoras. O Ramalhete estava tomando uma melancolia de mosteiro" (QUEIRÓS, 2001, v. I, p. 134). A imagem do Ramalhete como um mosteiro conota celibato, impossibilidade de procriação e renovação. Outro detalhe que é recorrente na descrição do Ramalhete é a Vênus Citereia e suas modificações, com importante destaque para a Deusa do amor (ora úmida e enegrecendo no canto, ora reluzente após a reforma e, finalmente enegrecendo e se deteriorando ao final da trama). Após a reforma e com a chegada de Maria Eduarda e sua relação com Carlos, a estátua está reluzente. Após o incesto consumado, a morte de Afonso e um segundo abandono, ela volta a se deteriorar.

A Chácara dos Meneses tem a sua planta desenhada na abertura do romance. Segundo as palavras do médico, a Chácara era “... uma casa grande, com aposentos largos, capaz de isolar perfeitamente cada habitante dentro dos muros de um quarto." (P75), isso já demonstra que não há laços entre os membros da família, a casa não é desenhada como uma lar, há severidade e dispersão. O horizonte da Chácara, assim como o do Ramalhete, 
tinha a sua visão prejudicada: “[...] as árvores que enchiam o jardim não permitiam uma vista muito nítida da Chácara..." (p.93). Orgulho do município, a Chácara é o símbolo dos Meneses, que não cogitam em sair de lá. Vilaça acusara o Ramalhete de ser uma edificação demasiadamente dispendiosa, Nina também alertara a família sobre a inutilidade da Chácara e de manter uma casa tão dispendiosa, caracterizada por ela como uma despesa inútil e que "poderia ser poupada, se não achassem todos que abandonar Vila Velha, e a mansão dispendiosa, fosse um definitivo ato de descrédito para a família" (primeira carta de Nina a Valdo Meneses. P. 24). Há tanto em Nina quanto em Vilaça o pragmatismo, o desapego ao passado e esses traços de modernidade estão em desencontro com o apego à tradição presente nas famílias. Do mesmo jeito que o Ramalhete era considerado fatal aos Maias, a Chácara era considerada um ambiente envenenado ou que se alimentava do sangue dos Menezes:

"Donana de Lara, por exemplo [...] ousara sugerir que se devia pedir ao Padre Justino para benzer a Chácara: o mal, dizia ela, estava arraigado na ruindade dos Meneses antigos, que haviam envenenado o ambiente da casa". (CARDOSO, 2009, p.71).

Enquanto as outras personagens são referidas como feitas de cal e pedra, a Chácara é lembrada como um ser de sangue e carne. Temos outro exemplo na primeira confissão de Ana que quando chegara a Chácara o imóvel ainda luzia "aos fogos do seu esplendor final” (CARDOSO, 2009. p.109). Seu pretenso sobrinho André, observava Ana, não como um ser humano, mas como uma espécie de acessório indispensável à Chácara como afirma: "Sobretudo Ana, que eu via incrustrada àquele ambiente, como se também fosse uma peça ou um detalhe dos móveis, tão firme como se representasse um juiz consciente da mais inapelável das sentenças." (CARDOSO, 2009. P.209) . A assertiva de André pode ser associada a um processo de emparedamento em vida de Ana nas paredes da Chácara, como Madaleine na Casa de Usher. Nina também comenta sobre o poder mortal da Chácara:

Ah, foi sempre este o mal daqui: fazer-me sentir prisioneira, sozinha e sem possibilidades. Sabia disto desde o primeiro instante, desde que pisei a beira daquela escada de pedra, e em que me envolveu, mortal, como um suspiro que se eleva da terra[...] (CARDOSO, 2009, p. 213).

De toda forma, Ana, como a moradora mais antiga seria a mais indicada para afirmar o quão era funesto o ambiente da Chácara.

Padre, acredito ter visto a presença tangível do diabo e, mais do que isto, ter alimentado com o meu silêncio, e a minha aquiescência, portanto, a destruição latente da casa e da família que há muitos anos são as minhas. (Padre, perdoe a minha veemência, mas desde que entrei para esta casa, aprendi a referir-me a ela como se tratasse de uma entidade viva. Sempre ouvi meu marido dizer que o sangue dos Meneses criara uma alma para essas paredes - e sempre andei entre estas paredes com certo receio, amedrontada e mesquinha, imaginando que desmesurados ouvidos escutassem e julgassem meus atos. Terei acertado, terei errado, não sei - a casa dos Meneses esvaiu-me como uma planta de pedra e cal que necessitasse do meu sangue para viver. (CARDOSO, 2009, p. 108). 
Ana perdeu a seiva, se deixou esvair pelas paredes da Chácara. Em Nina houve a resistência, ela lutou contra a morte e ao morrer a casa se esvaiu junto a ela.

Diferente do Ramalhete, a Chácara não passa por reformas como um processo de renascimento, já que a família mudou-se para lá no início da derrocada financeira, mas as lembranças das personagens deixam claro que a Chácara fora muito luxuosa e opulenta em tempos passados, como destacado em um dos depoimentos de Valdo: "Ah, não havia dúvida de que tudo aquilo no entanto conhecera melhores épocas, trato mais apurado das touceiras onde vicejava livremente o melão-de-são-caetano, repontavam ângulos de canteiros ainda cercados de pedras brancas ou de bojos de garrafas emborcadas." P47. O depoimento de Valdo rememora a Casa nos tempos da sua mãe, Malvina Meneses, tempos de abundância, ainda impressos nos móveis e objetos decorativos da Chácara:

[...] aquele ambiente tão característico de família, com seus pesados móveis de vinhático ou de jacarandá, de qualidade antiga, e que denunciavam um passado ilustre, gerações de Meneses talvez mais singelos e mais calmos; agora uma espécie de desordem, de relaxamento, abastardava aquelas qualidades primaciais. Mesmo assim era fácil perceber o que haviam sido, esses nobres da roça, com seus cristais que brilhavam mansamente na sombra, suas pontas semiempoeiradas que atestavam o esplendor esvanecido, seus marfins e suas opalinas - ah, respiravam ali conforto, não havia dúvida, mas era apenas uma sobrevivência de coisas idas. Dir-se-ia, ante esse mundo que se ia desagregando, que um mal oculto o roía, como um tumor latente em suas entranhas. (CARDOSO, 2009, p. 136-137)

As expressões relativas a sombra, penumbra, descaso, desleixo e desintegração são recorrentes nas passagens. Isso mostra que os Meneses insistiam em manter o brilho de tempos idos, de viverem num passado glorioso. Mas o atual ambiente desleixado e decadente destoa do que eles pensam ainda representar.

Enquanto Eça de Queirós inclui uma estátua simbólica da Deusa Vênus no jardim do Ramalhete, Lúcio Cardoso traz para o seu jardim estátuas representando as quatro estações, e todas elas em processo irreversível de ruína. Enquanto a Vênus do Ramalhete enegrecia com a umidade das ramagens silvestres, com as estátuas da Primavera e do Verão acontece algo semelhante:

Era ao fundo, lado direito do Pavilhão, onde antigamente havia uma clareira limitada por quatro estátuas representando as Estações. Só o Verão ainda se fazia ver de pé, e a parte inferior da Primavera, em cujo interior, como de dentro de um vaso, crescia uma vigorosa samambaia dominando os bordos partidos (p.109)

[...] Tratava-se de uma das partes menos frequentadas do jardim, o que desembocava lateralmente sobre o Pavilhão, espraiando-se numa clareira que antigamente fora limitada pelas estátuas das quatro estações, e que hoje só restava intacta a do Verão. [...] A estátua do Verão sobressaía serena de um maciço escuro, um tufo de samambaias brotando do seu interior como de dentro de um vaso. (CARDOSO, 2009, p. 279-280).

A atmosfera selvagem e desleixada é outro elemento presente nos dois romances em relação às casas com a persistente invasão de plantas, ramagens ou ervas daninhas. É 
possível encontrar a invasão descontrolada de elementos naturais como uma espécie de praga irremediável. As duas edificações são tomadas por forças da natureza que tomam dimensões selvagens e destruidoras. A presença das plantas que pode denotar um locus amenus toma uma dimensão exagerada e torna o ambiente incômodo, desleixado e inabitável.

Em anotações em seu diário, datadas em 16/08/1950, Lúcio Cardoso menciona que observações feitas em suas andanças povoaram o seu imaginário e o ajudaram a compor as suas obras. Em visita a uma fazenda, discorre:

O mistério da fazenda de Penedo me obseda - que vida houve lá, que ecos de civilização sacudiram seus muros, que nomes de poder e de fartura viveram ali a sua legenda? D. Siri, proprietária da casa onde me acho, (...) avisa-me que a fazenda é mal-assombrada. E não me resta nenhuma dúvida: tão grande casarão, abandonado ao silêncio e à devastação só pode constituir um pesadelo. Em torno dele a vida foge espavorida, só os espinheiros e as urtigas crescem com sombria ferocidade, enquanto os camaleões e os escorpiões se aninham sob as pedras esverdeadas pelo musgo. (CARDOSO, 1970, p. 111-112).

Percebe-se que a infestação de bichos e plantas em alguns ambientes dos romances não é feita de forma aleatória, mas para simbolizar o pesadelo, o martírio e o abandono presente nas casas e nos seus habitantes. Há, nos dois romances, a invasão de elementos naturais, a persistência da umidade nos cantos, muitas teias de aranha, poeira, ratos, baratas e musgo. Os ambientes, antes aconchegantes e receptivos, tornam-se repulsivos. O Padre, frequentador da Chácara desde os tempos áureos, reconhece que a degradação familiar e da casa aconteceram em conjunto e que tudo começou com a morte da matriarca:

Na verdade, há muito tempo não vinha à Chácara, se bem que outrora ali tivesse passado muitas vezes, a fim de assistir minha boa amiga, a mãe de Sr. Valdo, imobilizada pela paralisia numa cadeira de rodas. Desde que ela morrera - numa tarde escura, que parecia pressagiar a atual decadência da casa - eu nunca mais voltara [...]

A varanda, por exemplo, circundada no alto por uma barra de vidros de cor, parecia maior porque dela haviam retirado grande número de móveis que ali conhecera. As colunas estavam quebradas nas bordas e as árvores do jardim, nessa intimidade própria do abandono, agarravam-se à rampa e ameaçavam invadir $o$ interior onde nos achávamos. Um galho de jasmineiro, florido e audacioso, despencava-se até quase o centro da varanda. Ah, via-se bem que a voz de Dona Malvina não mais escoava naquele mundo: a desagregação apoderava-se dele e aos poucos ia devorando a graça austera e sólida de seu renome.

Decerto a casa é a mesma, com sua varanda, suas colunas, seus quartos e todo o poderoso mundo vegetal que a rodeia. $\mathbf{E}$ se dela subtraíram alguma coisa essencial - a alma, talvez - nem por isso se modificou sua fria estrutura de pedra e cimento. (CARDOSO, 2009, p. 370).

Mais um ponto a ser destacado na caracterização das casas seria o processo de antropomorfismo e as forças da natureza imprimindo os tons de suspense, assombro e tristeza do ambiente. A representação da Chácara e do Ramalhete como seres humanos são evidentes na evolução das narrativas. O Ramalhete interage com as personagens e os 
acontecimentos, principalmente no início do romance, durante o fatídico desenlace amoroso entre Pedro e Maria Monforte. Quando Monforte abandona Pedro e ele, consumido pela traição, volta ao Ramalhete à procura do pai e com o filho Carlos nos braços, do lado de fora do Ramalhete, "as pancadas sucessivas de chuva batiam a casa, a quinta, num clamor prolongado; e as árvores, sob as janelas, ramalhavam num vasto vento de inverno." (QUEIRÓS, 1997, v.1 p.1069). Dentro da casa havia o movimento dos criados, que já sabiam da problemática do abandono e "se moviam em pontas de pés, com a lentidão contristada de uma casa onde há morte”. (QUEIRÓS, 1997, v.1 p.1072)

As cenas passadas entre Afonso, inquieto, e Pedro desesperado, envolviam marcas de tristeza e suspense:

Um arrepio confrangeu o velho, e quando chamou, a voz de Pedro veio do negro da janela; estava lá com a vidraça aberta, sentado fora na varanda, voltado para a noite brava, para o sombrio rumor das ramagens, recebendo na face o vento, a água, toda a invernia agreste. (QUEIRÓS, 1997, v.1, p. 1072).

Enquanto isso, o clima triste da casa e do tempo chuvoso e frio ecoavam e combinavam com o estado de espírito de Pedro, dilacerado pelo abandono e pela traição, pouco antes do suicídio:

\begin{abstract}
Sentou-se longe da luz, ao canto do sofá, ali ficou mudo e entorpecido. Muito tempo só os passos lentos do velho, ao comprido das altas estantes, quebraram o silêncio em que toda a sala ia adormecendo. Uma brasa morria no fogão. A noite parecia mais áspera. Eram de repente vergastadas de água contra as vidraças, trazidas numa rajada, que longamente, num clamor teimoso, faziam escoar um dilúvio dos telhados; depois havia uma calma tenebrosa, com uma sussurração distante de vento fugindo entre ramagens; nesse silêncio as goteiras punham um pranto lento; e logo uma corda de vendaval corria mais furiosa, envolvia a casa num bater de janelas, redemoinhava, partia com silvos desolados. (QUEIRÓS, 1997, v.1, p. 1073).
\end{abstract}

O ambiente do Ramalhete acompanha os acontecimentos e, muitas vezes acrescenta suspense às cenas:

No seu quarto, ao lado da livraria, Afonso não pôde sossegar, numa opressão, uma inquietação que a cada momento o fazia erguer sobre o travesseiro, escutar: agora, no silêncio da casa e do vento que calmara, ressoavam por cima, lentos e contínuos, os passos de Pedro. (QUEIRÓS, 1997, v.1, p. 1074).

Após essa calmaria e do clima de suspense, Afonso ouve o tiro e encontra Pedro morto em cima de uma poça de sangue. Com a morte de Pedro, o Ramalhete morre também por longos anos até o retorno de Carlos, já adulto. E esse retorno, prometido como um renascimento, não passará de um último suspiro. Após os acontecimentos que culminaram no incesto e por consequência na morte de Afonso, o Ramalhete é fechado para sempre. 
Vale ressaltar que após Carlos ter cometido o incesto, retorna ao Ramalhete, acreditando poder seguir sua vida sem problemas, ao lado do avô. Chegando lá, o interior ainda era treva e surge Afonso com uma luz em sua direção. Afonso da Maia aparecia lívido, aterrorizado por já saber da relação incestuosa entre seus netos:

Pé ante pé, subiu as escadas ensurdecidas pelo veludo cor de cereja[...]. A luz surgiu - e com ela o avô em mangas de camisa, lívido, mudo, grande, espectral. Carlos não se moveu, sufocado; e os dois olhos do velho, vermelhos, esgazeados, cheios de horror, caíram sobre ele, ficaram sobre ele, varando-o até as profundidades da alma, lendo lá o seu segredo. Depois, sem uma palavra, com a cabeça branca a tremer, Afonso atravessou o patamar, onde luz sobre o veludo espalhava um tom de sangue: - e os seus passos perderam-se no interior da casa, lentos, abafados, cada vez mais sumidos, como se fossem os derradeiros que devesse dar na vida. (QUEIRÓS, 1997, v.1, p.1507).

Carlos observa o avô, antes da sua morte, com o passo lento e arrastado sobre o veludo que espalhava o tom de sangue, sumindo no interior do Ramalhete, mas não percebia que ali também findara a dignidade e a força de toda a sua família. Ao ver a tragédia abatida em sua descendência e ter a certeza de que toda sua família ali findara, o "granítico" Afonso deu seus derradeiros passos e morreu, desgostoso e solitário ao pé da cascata, sobre a mesa de mármore e entre cedros do Ramalhete. "Uma réstia de Sol, entre os ramos grossos do cedro, batia a face morta de Afonso." (QUEIRÓS, 1997, v.1 p.1509). O empregado fiel da família rememora um diálogo que tivera com Afonso em tempos passados, quando tentou dissuadi-lo da vontade de voltar a morar no Ramalhete:

- Há três anos, quando o Sr. Afonso me encomendou aqui as primeiras obras, lembrei-lhe eu que, segundo uma antiga lenda, eram sempre fatais aos Maias as paredes do Ramalhete. O Sr. Afonso da Maia riu de agouros e lendas... Pois fatais foram. (QUEIRÓS, 1997, v.1, p. 1516).

Afonso ao tombar, seu corpo se agigantou, como uma grande estátua, e sua morte refletiu a morte do Ramalhete. Com ele se foi toda a esperança de dias melhores, da perpetuação da virtude e da moral e com a morte do Ramalhete, foi-se embora um nome, uma tradição. Após um período de dez anos, Carlos e João da Ega voltam para fechar definitivamente a casa e assim encontram o ambiente:

[...] a curta paisagem do Ramalhete, um pedaço de Tejo e monte tomava naquele fim de tarde um tom mais pensativo e triste: na tira de um rio um paquete fechado, preparado para a vaga, ia descendo, desaparecendo logo, como já devorado pelo mar incerto; no alto da colina o moinho parara, transido na larga friagem do ar; e nas janelas das casas, à beira da água, um raio de sol morria, lentamente sumido, esvaído na primeira cinza do crepúsculo, como um resto de esperança numa face que se anuvia. (QUEIRÓS, 1997, v.1, p.15371538)

Os dois amigos reparam no jardim e concluem que a antiga visão esplêndida do Ramalhete foi escondida para sempre por outras construções mais modernas. A casa 
estava "presa" pela modernidade e não mais poderia ser contemplada. Além disso, os tons de destruição nessa antiga parte paradisíaca da casa ficaram cada vez mais evidentes:

Ega sentara-se também no parapeito, ambos se esqueceram num silêncio. Embaixo o jardim, bem areado, limpo e frio na sua nudez de inverno, tinha a melancolia de um retiro esquecido, que já ninguém ama: uma ferrugem verde, de umidade, cobria os grossos membros da Vênus Citereia; o cipreste e o cedro envelheciam juntos, como dois amigos num ermo; e mais lento corria o prantozinho da cascata, esfiando saudosamente, gota a gota, na bacia de mármore...” (p. 290, v2)

Durante a peregrinação de Carlos e Eça ao Ramalhete abandonado há uma nítida sensação de nostalgia e pessimismo, além do abandono e da dispersão que acaba por sugerir a própria dispersão dos Maias. O fim do Ramalhete era o espelho do fim de um clã tão tradicional. Carlos Reis reforça essa opinião com a seguinte assertiva:

Esse pressentimento expressa-se a partir das referências ao espaço do jardim: é a "melancolia do retiro esquecido", isto é, de certo modo extinto; é a "ferrugem verde" que corrói o símbolo (Vénus Citereia) de um amor (o de Maria Eduarda) definitivamente perdido... é o próprio "prantozinho da cascata, esfiado saudosamente", como se necessário fosse anunciar o desgosto e a amargura perante as indeléveis marcas deixadas (nas coisas e nas pessoas) pelo fluir irrefreável do tempo. (198,. p.184)

Além das referências à ferrugem, umidade e o funesto mármore, há também um destaque para os ciprestes e os cedros, árvores que, respectivamente, segundo o Dicionário de Símbolos: "Graças a sua longevidade e à sua verdura persistente, é chamada árvore da vida... Árvore funerária em todo o mediterrâneo" (CHEVALIER \& GHEERBRANT, 2000, p. 250) e o cedro "um emblema da grandeza, da nobreza, da força e da perenidade" (CHEVALIER \& GHEERBRANT, 2000, p.217). Árvores que simbolizam a vida mas que também são símbolos fúnebres, estão em pares guardando o quintal da casa, observando a finitude das várias gerações dos Maias.

Saindo do espaço do quintal e jardim e partindo para dentro do Ramalhete, o cenário se apresenta da mesma forma triste e melancólica. Eça de Queirós apresenta o Ramalhete como uma personagem que está morta após um período de agonia:

Ao entrar no Ramalhete, Ega sentia uma longa saudade, pensando no lar feliz e amável que ali houvera e que, para sempre, se apagara. Na antecâmera, os seus passos já the pareceram soar tristemente, como os que se dão numa casa abandonada. Ainda errava um vago cheiro de incenso e de fenol. No lustre do corredor havia uma luz só e dormente.

- Já anda aqui um ar de ruína, Vilaça [...]

Entraram no escritório de Afonso, onde durante um momento se ficaram aquecendo ao lume. O relógio Luís XV bateu finalmente as nove horas - depois a toada argentina do seu minueto vibrou um instante e morreu. [...]

Dentro dos cômodos do Ramalhete aparecem mais indícios de abandono, ruína e destruição. Em uma casa que desde sempre era mal iluminada e "todo rumor de passos morria”, adquiriu um tom ainda mais silencioso, triste, destruído e abandonado. 
E os dois amigos atravessaram o peristilo. Ainda lá conservavam os bancos feudais de carvalho lavrado, solenes como coros de catedral. Em cima, porém a antecâmara entristecia, toda despida, sem um móvel, sem um estofo, mostrando a cal lascada dos muros. ... Depois, no amplo corredor, sem tapete, os seus passos soaram como num claustro abandonado. Nos quadros devotos, dum tom mais negro, destacava aqui e além, sob a luz escassa, um ombro descarnado de eremita, a mancha lívida duma caveira. Uma friagem regelava... No salão nobre os móveis de brocado, cor de musgo, estavam embrulhados em lençóis de algodão, como amortalhados, exalando um cheiro de múmia a terebintina e cânfora. E no chão, na tela de Constable, encostada à parede, a condessa de Runa, erguendo o seu vestido escarlate de caçadora inglesa, parecia ir dar um passo, sair do caixilho dourado, para partir também, consumar a dispersão de sua raça...

— Vamos embora - exclamou Ega - Isto está lúgubre! (QUEIRÓS, 1997, v.1 p.1535)

O interior destruído e a representação da dispersão da raça são descritos como uma rememoração de todo o caminho da decadência: o lar feliz e amável em tempos longínquos aparece mais uma vez comparado aos mosteiros, o vazio interior e a falta da luminosidade são ressaltadas, mas principalmente os móveis envolvidos em lençol como amortalhados atestam a morte da personagem. E isso se confirma quando Carlos "Voltou a olhar para a sala, onde todos os móveis desapareciam sob os largos sudários brancos" v2 p.290).

Ainda sob a forte emoção por conta das lembranças passadas no Ramalhete, os dois amigos são surpreendidos com mais um acontecimento significativo a respeito do enterro definitivo do casarão:

A porta cedeu; e toda a emoção de repente findou, na grotesca, absurda surpresa de romperem ambos a espirrar, desesperadamente, sufocados pelo cheiro acre dum pó vago que lhes picava os olhos, os estonteava. Fora o Vilaça, que seguindo uma receita de almanaque, fizera espalhar às mãos cheias, sobre os móveis, sobre os lençóis que os resguardavam, camadas espessas de pimenta branca! E estrangulados, sem ver, sob uma névoa de lágrimas, os dois continuavam, um defronte do outro, em espirros aflitivos que os desengonçavam. (QUEIRÓS, 1997, v.1 p.1537)

O procurador Vilaça, aquele que sempre dizia que "eram fatais aos Maias as paredes do Ramalhete" , através da leitura de um almanaque, sugeriu cobrir os móveis com pimenta, o que, segundo ele, conservaria os móveis por mais tempo. Este ato pode simbolizar um ritual de purificação, a representação da chamada "pá de cal", do sepultamento da casa, da tradição, do respeito e da continuidade dos Maias.

A derrocada e a dispersão da família associadas ao tombamento das casas são retratadas de forma semelhante ao final dos dois romances. No Ramalhete, após acompanhar todos os acontecimentos trágicos - o suicídio de Pedro, o incesto, a morte de Afonso da Maia, a partida de Maria Eduarda e a mudança de Carlos, Eça de Queirós traduz a casa como uma espécie de jazigo:

[...] Depois, na rua, Carlos parou, deu um longo olhar ao sombrio casarão, que naquela primeira penumbra tomava um aspecto mais carregado de residência eclesiástica, com as suas paredes severas, a sua fila de janelinhas fechadas, as grades dos postigos térreos 
cheias de treva, mudo, para sempre desabitado, cobrindo-se já em tons de ruína. (p.293. v2.)

E, sobre a rua deserta, cerrou-se finalmente para um grande luto o portão do Ramalhete (p. 264 v2)

Foi no espaço do Ramalhete que Pedro acelerou o fim de sua família ao cometer o suicídio, a casa que mesmo com todas as esperanças de renascimento e promessas de grandezas futuras vê Carlos fracassar social e moralmente e morrer simbolicamente ao ver o avô sucumbir vítima do desgosto provocado por seus atos. Findada a família, findado o Ramalhete.

$\mathrm{Na}$ Chácara, "uma mansão dispendiosa [...] a casa que apodrece no contraforte da serra.” p.39, o processo de humanização, ruína e aniquilação começa a se dar logo após a morte de Malvina Meneses, piora com a chegada de Nina e finaliza com o seu retorno, quinze anos depois. Assim como Eça de Queirós adjetivou o Ramalhete com tons humanizados, mas de forma desenganada e moribunda ligada aos acontecimentos da família, Lúcio Cardoso o fez com as descrições da Chácara. Pode-se perceber que a Casa é retratada como um espaço que já conheceu tempos melhores, mas que de repente começou um processo de deterioração e esse desgaste foi percebido após a morte da matriarca, como observa o médico da cidade em um de seus depoimentos:

Por exemplo, caminhando, constatava que aquela alameda era longa demais, que os canteiros não tinham nenhum trato, que além, entre as folhas, a Chácara repontava suja e triste. Desde quando, em que momento exato ela se petrificara, qual o motivo que a tornaria muda, ela, que sempre primara pela vivacidade em meio às suas flores? Lembrava-me ainda dos tempos de Dona Malvina, desde cedo com a tesoura de podar nas mãos, um preto empurrando a cadeira de rodas na areia que fulgia ao sol da manhã. Ainda havia vitalidade, ainda havia saúde percorrendo os alicerces agora podres. A presença de Dona Malvina vitalizava toda uma geração de Meneses condenada à morte.

O jardim da Chácara tem importância similar à exibida no jardim do Ramalhete e, durante os anos de abastança tinha melhor aspecto pois era tratado diretamente pelas mãos de Malvina Meneses, sempre vista com uma tesoura de podar nas mãos a cuidar das flores, dos canteiros e a extrair as ervas daninhas. Valdo Meneses descreve com saudades das épocas áureas se referindo ao jardim: "O jardim, nessas primeiras sombras, recendia a funcho e magnólia, um cheiro entre doce e cortante, persistente, que a despeito meu me lembrava épocas mais felizes. p. 477'. Mas, nos tempos atuais, o mesmo jardim guarda, além das estátuas das quatro estações avariadas e cobertas de vegetação um outro detalhe como o da cascata do Ramalhete: "Era uma fonte comum, circular, com bordas cravadas de conchinhas; o repuxo, dividido numa série de jatos, perpetuamente avariado, tinha ao centro uma cegonha triste que já faltava as pernas. p.373. Os itens que envolvem um permanente desmantelo e avario são comuns nas duas narrativas não só no interior das casas mas nos arredores, nos anexos e nos jardins.

Ao contrário do Ramalhete e como já mencionado, a Chácara não passa por mudanças nem reformas antes de testemunhar o próprio fim, mas a chegada da 
"estrangeira" Nina proporciona um novo tom a paisagem, mas, como o Ramalhete, é um tom que pressente e antecipa a sua própria ruína, como atesta Valdo Meneses em um dos seus depoimentos:

$\mathrm{Na}$ obscuridade, enquanto caminhava, via casa acesa, de janelas abertas, com uma ou outra sombra transitando em seus corredores, a Chácara, sempre mergulhada em sua calma, surgia diferente para quem conhecia seus hábitos. Era curioso de se ver, e havia encanto nisto - um sopro novo parecia alimentá-la e ela se erguia atenta, como na previsão de acontecimentos importantes. Não me lembrava de tê-la visto assim tão preparada, e possivelmente me orgulharia de sua nova atitude, se não trouxesse o coração pesado e não pressentisse que, como certos doentes graves, ela só abrisse os olhos para celebrar o próprio fim. (CARDOSO, 2009, p. 434-435)

Ainda na primeira estadia de Nina na Chácara, a mudança no seu aspecto também fora notada pelo farmacêutico, que observou mais pontos de iluminação na edificação que vivia sempre na penumbra, mas traz ressalvas à persistência do silêncio e a certa sobriedade que denotava humanidade ao ambiente:

No crepúsculo que já inteiro se difundia na atmosfera, a Chácara sobressaía com extraordinária nitidez: olhei-a de longe, com todas as janelas abertas e as luzes acesas. Ah, não restava a menor dúvida de que nem eu e nem ninguém estava acostumado àquele aspecto. Quem quer que a visse de longe, estranharia seu aspecto de coisa invadida e violada. No entanto, na metamorfose que a alterava, e isto desde o cimo até sua mais secreta estrutura, havia um silêncio, uma espera que lhe emprestava um dignificante tom humano. p. 440

De longe ainda, através da ramagem, distingui as luzes da Chácara. A fachada, que ia se descobrindo aos poucos ao jogo dessa claridade esbatida - mantidas pelo esforço de um gerador deficiente, as luzes esmoreciam com frequência - , adquiria um aspecto mortuário. (CARDOSO, 2009, p.477)

Após a partida de Nina para o Rio de Janeiro, a Chácara continuara a mesma, com seus aposentos isolados e isolando os moradores, mas a movimentação mudara, sempre na expectativa do seu retorno. Mas quanto ao retorno de Nina, já comedida pelo câncer que vai matá-la numa agonia lenta e severa, a casa vai também vai adoecendo e acelerando sua agonia rumo à morte. Nina sofre um mal físico e a Chácara sofre um mal espiritual. Em um dos depoimentos do médico, percebe-se que a Chácara possuía beleza em seu entorno e constituía importância nos arredores, mas agora sofria de uma deterioração concomitante ao câncer que consumia o corpo de Nina:

Dirão que isto talvez não passasse de impressão exagerada, mas a verdade é que de há muito eu pressentia um mal qualquer devorando os alicerces da Chácara. Aquele reduto, que desde a minha infância - há quanto tempo, quando a estrada principal ainda se apertava entre ricos vinháticos e pés de aroeira, tortuosa, cheia de brejos e de ciladas, um prêmio quase para quem se aventurasse tão longe... - eu aprendera a respeitar e a admirar como um monumento de tenacidade, agora surgia vulnerável aos meus olhos, frágil ante a destruição próxima, como um corpo gangrenado que se abre ao fluxo dos próprios venenos que traz no sangue. [...] Gangrena, carne desfeita, arroxeada e sem serventia, por onde o sangue já não circula e a força de esvai, delatando a 
pobreza do tecido e essa eloquente miséria da carne humana. Veias em fúria, escravizadas à alucinação de um ser oculto e monstruoso que habita a composição final de nossa trama, famélico e desregrado, erguendo ao longo do terreno vencido os esteios escarlates da sua vitória moral e purulenta [...] (CARDOSO, 2009, p.159)

Remontando às histórias fantasmagóricas, as ideias de desmazelo, de ruína, da invasão de elementos naturais, trevas e sombras, tão presentes no Ramalhete, aparecem em várias passagens da Crônica. As referências às janelas como os olhos das edificações também aparecem e se não estão fechadas, estão semicerradas ou estão abertas exibindo luzes vacilantes:

Chegamos ao Pavilhão e, sem necessidade de procurar muito, pude verificar as fendas que se abriam nos alicerces da casa, gretando os esteios fortes e bem plantados, disjuntando as pedras da base, exibindo enfim um desmazelo que se originara através dos anos, e que sem dúvida ameaçava a construção de um acidente, remoto ainda, mas já bastante visível nos seus primeiros e acusadores sinais. (410)

[...] voltava à janela, e sondava os tufos sombrios das árvores, as partes claras onde a areia brilhava, o matagal mais escuro ainda, espremido na distância, de onde vinha um hausto surdo, como se ali respirasse o próprio espírito da treva. P.269

Avançando ao meu encontro, a Chácara desnudava sua nova fisionomia: as janelas abertas como que vigiavam em plena escuridão, se bem que aquelas pupilas acesas não se movessem, e como que fixassem uma outra paisagem, acima e superposta àquela que constituía os velhos pastos em torno do lar que eu nascera. P.477

"Como acontece em quase todo interior, nossa cidade carecia de luz elétrica, cujo serviço era deficiente e malfeito, mas a Chácara, que tinha gerador próprio, ainda a possuía pior: era uma luz amarelada, sem constância, e que aumentava ou diminuía conforme a intensidade da corrente" (CARDOSO, 2009, p.72)

Os últimos momentos da Chácara são concomitantes ao velório de Nina, um momento crucial no romance. Os Meneses sempre isolados do resto mundo, ilhados e sem frequentar seus semelhantes, apenas em raríssimas ocasiões, sempre muito calados e austeros, os "estranhos Meneses" foram obrigados a abrir sua casa para os vizinhos e curiosos:

Confesso, ao me aproximar, suas aleias pareceram-me mais sombrias do que nunca. Muito ao fundo, num único traço negro, adivinhava-se o contorno da casa, com uma ou duas janelas iluminadas. Toda uma vida secreta, densa e reservada, inundava os limites em que ela se continha. "Estranhos Meneses", pensei de novo. E senti vir de toda a paisagem um frio que emanava menos da chuva do que da hostilidade que lhe era própria, e que pertencia àquela gente, sempre tão calada e austera. P.136

[...] não conservava mais a mínima dúvida de que essa invasão significava o fim - o fim completo dos Meneses. Os vizinhos se achegavam, e eram eles que denunciavam esse fim, como em pleno campo de urubus denunciam a rês que ainda não acabou de morrer. (CARDOSO, 2009, p.477-478)

Após o enterro de Nina, cada um dos Meneses toma um rumo diferente, o que demonstra a dispersão total da família; apenas Ana Meneses continua na Chácara. Doente, Ana aguarda a presença do Padre que atende ao seu chamado e se depara com um cenário 
lúgubre e fúnebre. Em Os Maias, Carlos da Maia, João da Ega e o Procurador Vilaça testemunham os últimos suspiros do Ramalhete. Na Crônica, esse papel cabe ao Padre Justino e a Ana Meneses. Ao abrir a porta do quarto do porão em que Ana resolveu passar os seus derradeiros dias de vida, o padre relata: "Diante da porta aberta, tremi, sentindo o hálito de mofo que vinha daquela escuridão, tal como se acabassem de romper brutalmente a integridade de um túmulo. P.304. Ao se acomodar no recinto para ouvir a confissão de Ana, preparando os rituais de extrema unção, reparou na desolação de todo ambiente, que apesar da sua importância em tempos passados, da relevância memorial para a cidade, estava em acelerado e irrefreável processo de ruína.

Ali estava ela, tombando, como devorada por um mal que vinha de suas próprias entranhas. Em meio à paisagem luxuriante e sem peias, conservava um estranho recato, como se estivesse voltada sobre as ruínas que a constituíam, e assim, cega, ainda meditasse sobre o nada existente no seu bojo, e desfiasse, isolada e dura, a memória dos seus dias idos p. 527

O último reduto, aquele quarto de porão onde um dia se abrigaram o amor e a esperança, estava prestes a ruir também, e fora aquele o abrigo que Ana elegera, como o faria a criatura ante a ameaça de uma inundação, escolhendo para abrigo a cumeeira da casa cercada. Naquele minuto preciso a casa dos Meneses desaparecia para sempre. Um último vislumbre de sua existência ainda se mostrava naquele catre de agonizante. P.535

Ela se achava deitada num catre feito de tábuas de caixote, sobre um colchão esburacado de onde irrompia a palha. Não pude ver logo seu rosto, mas percebi que ofegava. Aliás, no espaço acanhado reinava esse cheiro nauseabundo e morno, próprio de doentes vitimados por moléstia prolongada e malservidos pelo asseio. Por um momento, estonteado, julguei-me num desses casebres de pau a pique que servem de abrigo a míseros colonos, e não junto à única herdeira conhecida da orgulhosa família Meneses. (CARDOSO, 2009. P.524)

Com a morte de Nina, o processo de tombamento da Chácara foi acelerado e com a agonia de Ana, a Casa vibrou em uníssono findando o seu processo de apodrecimento. Com a dispersão de todos os membros da família, restou ao padre apenas lamentar a sorte dos Meneses e da Chácara:

Ainda tenho presente na memória a última vez em que a vi [casa], quando ia a meio a triste epidemia que liquidou nossa cidade. A Chácara dos Meneses foi a última a tombar, se bem que seu interior já houvesse sido saqueado pelo bando do famoso Chico Herrera. Vejoa ainda, com seus enormes alicerces de pedra, simples e majestosa como um monumento em meio à desordem do jardim. A caliça já tinha quase completamente tombado de suas paredes, as janelas, despencadas, batiam fora dos caixilhos, o mato invadia francamente as áreas outrora limpas e subiam pelos degraus já carcomidos - e no entanto, para quem conhecia a crônica de Vila Velha, que a vida ainda se ressumava ela, pelas fendas abertas, pelas vigas à mostra, pelas telhas tombadas, por tudo enfim que constituía seu esqueleto imóvel, tangido por tão recentes vibrações. (CARDOSO, 2009. P.523)

O interior já completamente vazio não continha os móveis envoltos em "largos sudários brancos" como o Ramalhete, mas tinha mesmo aspecto fúnebre com seu avançado estado de decomposição e seu esqueleto à mostra. A Chácara, assim como o 
Ramalhete fechara-se, para sempre, em um grande luto. A dispersão dos últimos habitantes do Ramalhete se repetira com os últimos habitantes da Chácara, findando as duas famílias que não conseguiram manter a tradição.

\section{REFERÊNCIAS}

BACHELARD, Gaston. A poética do espaço. Trad. Antonio de Pádua Danesi. São Paulo: Martins Fontes, 1993.

BARROS, Fernando Monteiro de. Do castelo à casa-grande: o “Gótico brasileiro", em Gilberto Freyre. Revista Só Letras. 2014

CANDIDO, Antonio. Literatura e cultura de 1900 a 1945 - panorama para estrangeiros. Literatura e sociedade. São Paulo: Companhia Nacional, 1965.

1993.

. Literatura Comparada. In: Recortes. São Paulo: Companhia das Letras,

CARDOSO, Lúcio. Crônica da casa assassinada. Rio de Janeiro: José Olympio, 1959.CARDOSO, Lúcio. Crônica da casa assassinada. 2. ed. Rio de Janeiro, Nova Fronteira. (1979)

CARDOSO, Lúcio. Crônica da casa assassinada. Edição crítica de Mario Carelli. 2 ED. Scipione Cultural. (1996)

CHEVALIER, Jean; GHEERBRANT, Alain. Dicionário de Símbolos: mitos, sonhos, costumes, gestos, formas, figuras, cores, números. Tradução de Vera da Costa e Silva et al. 15. ed. Rio de Janeiro: José Olympio, 2000.

HERDER LEXICON. Dicionário de símbolos. 5ed. Ed. Cultrix. São Paulo, 2002. HUTCHEON, Linda. Poética do pós-modernismo: História, teoria, ficção. Trad de Ricardo Cruz. Rio de Janeiro: Imago, 1991.

KRISTEVA, Julia. Ensaios de Semiologia. Tradução Luiz Costa Lima. Rio de Janeiro: Eldorado, 1971.

LUKÁCS, György. O romance histórico. Tradução Rubens Enderle. São Paulo: Boitempo, 2011.

MOISÉS, Massaud. A Literatura Portuguesa Através dos Textos. 25. ed. Ed. Cultrix. São Paulo, 1999.109

ORTIGÃO, Ramalho - As Farpas, Lisboa, Livraria Clássica Editora, 1942-1946. 15 vols. OSAKABE. Haquira. Fernando Pessoa. Resposta à decadência. Criar Edições. Curitiba. 2002

QUEIRÓS. Obra Completa. Vol. I. Editora Nova Aguilar S.A. Rio de Janeiro. 1997 REIS, Carlos. Estudos Queirosianos - Ensaios sobre Eça de Queirós e sua obra. Editorial Presença: Lisboa, 1999.

. Introdução a leitura dos Maias. Ed. Almedina Brasil: São Paulo, 2003.

2000. O essencial sobre Eça de Queirós. Ed. Imprensa Nacional: Lisboa,

ROSA, Alberto Machado da. Eça, discípulo de Machado? Lisboa: Editorial Presença, 1979. 
